\title{
The Nexus between Export Incentive and Export Performance in Ethiopia
}

\author{
Tadele Asfaw Ayen ${ }^{1} \quad$ Dawit Gebre medhin ${ }^{2}$ \\ 1.Ethiopian Customs Commission, Addis Abeba, Ethiopia \\ 2. Ethiopian Civil Service University, College of Finance, Development and Management, Addis Abeba \\ Ethiopia
}

\begin{abstract}
The purpose of this study is to examine the nexus between export incentive and Ethiopian export performance from the year 1983 to 2017 . The study is conducted by quantitative research method by using time series econometrics analysis. The study employs an Autoregressive Distributed Lag (ARDL) bound test model to cointegration in order to investigate the long run relationship and Error Correction Model (ECM) for the short-run relationship between export and export incentive, real GDP, real exchange rate, gross capital formation, external debt stock and inflation rate. The long-run empirical result using the bound test reveals that there is a stable longrun relationship between real export and explanatory variables. The study finds out that during study period the Ethiopian export composition mainly focused on primary product and Europe was main export destination. In the econometric analysis, the study finds that export incentive has the significant positive impact on export performance both in short run and long run. Similarly, real GDP and inflation have the significant impact on export performance whereas gross capital formation, real exchange rate and external debt have the insignificant impact in short run and long run during the study period. Further, in short run one year lagged values of export and external debt have positive impact on export performance. The coefficient of equilibrating error term suggests that the speed of adjustment (feedback effects towards the long run equilibrium) takes few years for full adjustment when there is a shock in the system. Therefore, export incentive and export performance in Ethiopia have direct relationship both in the short run and in long run.
\end{abstract}

Keywords: ARDL, Ethiopia, export incentive, export performance

DOI: $10.7176 / \mathrm{JESD} / 12-5-02$

Publication date:March $31^{\text {st }} 2021$

\section{Introduction}

Promoting export is prominently figured in the minds of the most countries policy-makers for economic growth and development (Kneller \&Pisu, 2004). In stimulating export and investment, different countries offer the diverse types of incentives based on the level of development (Ahuja, 2001). This universal type of providing incentive is popular in the form of financial and non-financial incentives such as tax breaks, duty drawbacks, investment allowances, export-promotion activities, providing free information about foreign markets, financing market researchers, and export credit insurance (Kneller \&Pisu, 2004).

Using export promotion strategies and by providing reasonable export incentives; East Asians (i.e. South Korea, Taiwan, Hong Kong and Singapore) achieve success in gigantic economic growth and industrialization. From the last three decades, these countries increased their world market share because of great weight to the export sector (Ashenafi\&Getaneh, 2014). The Asian tigers (Indonesia, Malaysia, Philippines, and Thailand) also have evocative successful countries in export performance by export promotion strategy. Similarly, newly industrialized countries (China, India, and Vietnam) have been an attempt at raising shares of world exports shares by using export incentive (Tran et al., 2012).

The government of Ethiopia provides an official incentive to export sectors starting from 2001 in order to boost export. The government provides different financial and non-financial incentives such as abandoning export tariffs and taxes, increasing license facilities, easily accessible borrowing and currency devaluation (Azmera, 2013). Similarly, under proclamation no 768/2012 enlighten the major export incentives provided by the government of Ethiopia are duty drawback scheme, voucher scheme, bonded export factory scheme, bonded export manufacturing warehouse scheme, the bonded input supplies warehouse scheme and industrial zone scheme.

Even though, providing export incentive has its own significance in increasing export performance; there is a huge gap between import and export amount of Ethiopia. According to WTO statistics, the Ethiopian export performance of 2016 was 4,612 million dollars, on the contrary, the country imports 16,588 million dollars. This shows that there is nearly 12 million dollar deficit in terms of export-import equality or balance of trade. In addition, the statistics show that the world market share of total export of merchandise trade of Ethiopia was 0.03 in 2016, it is closely insignificant. These statistics confirm that the outcome of Ethiopian export performance is still unsatisfactory.

The motivation behind this study is that although, export incentives definitely affect export performance in some circumstances; it is controversial, it is not the only force to increase export performance and providing export 
incentive is not always effective in the increasing export performance. Further, Ethiopian government provides export incentive since 2001 but the outcome of export performance is still disappointing to obtain a foreign exchange and it is unable to finance rampant nature of country's import. Therefore, based on the above-highlighted issues, this study is important to identify whether the provided Ethiopian export incentive has the significant impact on Ethiopian export performance or not.

\subsection{Statement of the Problem}

The government of Ethiopia set out and implements different types of policies and strategies in order to boost the country's export, but the export performance is not improved more than $12 \%$ of GDP. Besides, the export sector concentrates only a few types of agricultural products such as coffee and other traditional products. The export sector also has lack of competitiveness and the small share of private sectors (Azmera, 2013).

The study which was conducted by Tewelde(2015) concludes that incentives to the export sector have robustly improved export value and volume of Ethiopia. Similarly, another empirical evidence conducted by Ashenafi and Getaneh (2014) also show that there is a positive relationship between export incentive and export growth.

Unlike the above studies, the study conducted by Mulu and Ashagre (2017) displays that the provided incentives for exporters are insufficient to motivate export sector. More importantly, the effectiveness of the export incentives has a problem of efficient bureaucracy, lack of coordination and rent-seeking, and it has an insignificant impact on export performance. To support this study, recently on October 11, 2017, National Bank of Ethiopia devaluates exchange rate by $15 \%$ on behalf of inadequate performance of export sector to earn foreign exchange (Muluken, 2017). This shows that there is mixed result in the study of the same subject matter. In addition, according to the data of National Bank of Ethiopia, the recent years total export growths are marginal. Hence, this will create ambiguity for decision making about export incentive whether to continue providing incentive or to reverse the existing policy to correct the current export deficiency.

The identified gap is filled by the researcher using secondary data analysis and by the inclusion of other important determinant variables which have the significant effect on export performance using Autoregressive Distributed Lag (ARDL) model in the time series econometric analysis. The model is recently developed and important to identify the relationship between macroeconomic variables in a single equation of time series setup (Kripfganz\&Schneider, 2016). Therefore, this study is conducted in order to examine the nexus between the provided export incentive and Ethiopian export performance. This research paper is able to answer the following research questions.

i. What is log run relationship between export incentive and export performance?

ii. What is short-run relationship between export incentive and export performance?

\section{Literature Review}

First of all, it is necessary to explain what incentives and export incentives are. According to Azasu (2004) incentives in general can be defined as "an award given out to group or individual when the predetermined objective is achieved'. This definition suggests that organization provide incentives to individual or group for work done and have significant influence on the performance of work. Therefore, these types of incentives bestowed when the planned task is accomplished.

Unlike to the above definition, incentives can also be defined as " any measureable advantage given for any enterprise or any business activities by a government or by direction of government with excluding the others" (UNCTAD, 2003). This definition clarifies that incentives are a special advantage provided for selected sectors or groups in order to increase the production or in order to continue business activities. Such types of incentives are provided before and after the task is completed since all legalized sectors use the incentives whether their performance is good or bad. Likewise, OECD defines investment incentives as designed action to influence the size, location or industry of a foreign direct investment project by reducing relative cost, and altering the risks attached to investment (Miroslava, 2013).

\subsection{Overview of Export Incentives in Ethiopia}

According to investment commission of Ethiopia (2016) the provided incentives for both domestic and FDI are divided into investment incentives, export incentives and remittance of capital. Export incentives can also be divided into fiscal incentives and non-financial incentives. Financial incentives include customs duties exemption and income tax exemption. Non- financial incentives include free import machinery and necessary equipment with supplier's credit for those investors engaged in production of exportable products, National Bank provides up to $70 \%$ of their investment capital loan for those investors involved in areas of agriculture, manufacturing and agroindustry, and the government cover $30 \%$ of the cost of infrastructure (access to road, water supply, electricity, telephone lines) for investors investing in the industrial zone development.

According to proclamation number 294/2001, the Ethiopian government provides an incentive to export 
sector for the reason that to increase export volume and increase foreign currency reserve. Under this proclamation on article 4, Duty Drawback Scheme, Voucher Scheme, and Bonded Manufacturing Warehouse Scheme are duty incentives provided to the export sector.

The above proclamation was amended by proclamation no768/2012, in addition to the above incentives the bonded export factory, the bonded input supply warehouse scheme and the industrial zone scheme are additionally provided by the government are Duty Draw Back Scheme, Voucher Scheme, Bonded Export Factory Scheme, Bonded Export Manufacturing Warehouse Scheme, The Bonded Input Supplies Warehouse Scheme and Industrial Zone Scheme

\subsection{Theoretical Literature Review}

Incentive theory appears with the division of labor and exchange of Adam Smith. The division of labor provokes the need for delegation and implicit incentive provided in historical contracts appears probably in agriculture when a landlord contracts with his tenant. Through time the theory of incentive developed and inculcated in different sectors (Laffont\&Martimort, 2001).

However, the neoclassical economic theory argues that providing an incentive to invest leads violates horizontal equity or good tax system. Providing an incentive to certain group leads to inequality because it distorts the efficient allocation of resources. This justifies government is intervening to investment sector and it leads to market failure. Market failure is occurring because of externalities, information asymmetries and uncertainties, equity and political economy (Jordaan, 2012).

UNCTAD (2004) also claims that, for the purpose of increasing the amount of export, governments strongly encourage export sectors and contribute different types of investment as well as export incentives. Moreover, to pursue development strategies incentives are considered as tools and if it is used properly, they can compensate week business environment. Incentives are also important in correcting failure of market and benefits from externalities of production.

Neo-mercantilism is a policy regime which mainly encourages exports, reduces imports, controls capital movement and centralizes currency decisions by government. Germany, French, Netherlands, Austria, as well as Scandinavian countries, used Mercantilism views in the late $19^{\text {th }}$ century. Using trade protection like tariffs and non-tariff barriers (quotas, health, environmental, standardization, and exchange-rate), State subsidies for domestic producers, strategic trade policy, infant industry, Import-substitution for promoting industrialization and export promotion are major actions in neo-mercantilism (Ditter, 2010).

The new theories have made based on positive theories and give much less emphasis to normative theory. Partly, it is because of normative theory never used nor needed all the assumptions that were commonly used in the positive theory and also basic ideas of the old normative theories are particularly solid, robust ideas and could not be easily displaced. Nevertheless, the new trade models have succeeded in convexity assumption and policymaking (Bliss, 1987).

The Infant Industry Argument gives justification for the protection of initial stages of their establishment. It argues about why the production capacity of firms became low in poor infrastructure, lack of skilled laborers and high-cost production and cannot compete with foreign producers in the domestic market. Therefore, hopefully with reduction of cost of doing business the firm's production also rises (Kemal, 1979). Correspondingly, Robert Lucas raises two points about the reasons for infant industry protection. It is because of the time path of learning difference across industries and because of the externalities of an infant industry (Krueger \&Tuncer, 1984).

\subsection{Empirical Investigation}

Government policymakers take different measures for low economic performance. Providing investment incentives are tools for enhancing investment and economic growth. In theory, providing a certain amount of incentive to definite sector improves the overll economy and incentive increases performance as well as the quality of investment (Jordaan, 2012). Thus, there are controversies about the efficiency of fiscal incentives among other things; some studies strengthened non-financial incentives as a major criterion for rising FDI whereas other studies ranked financial incentives not, as essential pre-requisites for foreign investment and slight decline following the abolition of tax holidays. This can raise a question why incentives are so popular despite the fact that their effects are either minor or unknown (Fowowe, 2013).

Likewise, the empirical evidence about the effectiveness of export incentive on export performance shows diverse results. The study conducted by Defevery and Riano (2012) using a heterogeneous-firm model tried to analyze the economic implication of export incentive in which firms exporting all their output receive an advalorem sales subsidy in China. They conclude about Chinese pure export subsidy leads to welfare loss because of users of export incentives are not productive as that of non-users of export incentive. The industries officially used export incentive provided by the government is not that much productive as that of domestic producers who have not used export incentive. Due to the export incentive the country's revenue undermines and eliminating export subsidy results welfare gain to Chinese citizens in related to trade cost. 
Unlike the above study, the research conducted by Julian and Ali (2009) on the exporter of Australia by convincing sampling showed the result of Australian export incentive has significant impact on entering diversification into new market. This shows that export incentive is important for increasing the volume of exporting products.

Similarly, the study conducted by Munch and Schaur (2015) on the export promotion of Denmark's showed a result that due to export promotion small firms increases export performance by raising value added, employment and productivity. Especially, the export promotion increases the productivity of service sector as compared to that of firms sector. In addition, the study conducted by Defever et al. (2017) in Nepal shows the result of export incentive has the positive effect on certain products export and it is also important to achieve export diversification.

Correspondingly, Bangladesh also increases the export performance by providing export incentive as compared to Pakistan. The government of Bangladesh provides duty exemptions, low tax rates, export finance, and others to textile export sectors. The export incentive has great significance to increase the export performance of the country. The industries planted from Pakistan through time-shifted to Bangladesh and India due to lower export incentive (Ahmad, 2015).

In Africa empirical findings displayed that the provided export incentives are land, tax holidays, exemption from income tax, duty free import of inputs, exemption from export tax, creating special zones with full facilities and infrastructures are some of export incentive schemes provided by governments. In one hand, empirical findings argued providing export incentive has the significant impact on increasing export performance. On the other hand, the other studies figure out reasons why export incentives are weak to boost export performance in some countries due to many reasons some of them are rent-seeking, insufficient incentive, bureaucratic reasons i.e. different documents required, corruption and other reasons. The following discussions show the empirical findings of export incentive and export performance relationship.

The study conducted by Motswapong and Grynberg (2014) in Botswana shows that textile and close export performance was decreased due to economic crises and phasing out of export incentive. The government provides the incentive to export sector of textile and close like labor grant incentive to skilled and semi-skilled labor, tax holiday and a training scheme to improve the skill levels of the citizens. Phase out of these incentives leads to an insignificant increase in export performance of the country. This indicates export incentive is one factor of the performance of the country's export.

On the contrary to the above study, the research conducted by Worlu (2011) in Nigerian showed that the provided export incentive was not effective because oil export continues the lion share of country's export, it accounts $95 \%$ of total export. In addition, the small number of merchants participates in the export sector of Nigeria and the researcher concludes that the country's export incentive scheme was not effective.

In Ethiopia also some studies conducted on the nexus between export incentive and export performance. Like that of world and African studies the relationship between export incentive and export performance is inconclusive.

First study conducted by Ashenafi and Getaneh (2013) showed a result of export incentive has the positive effect on increasing export performance both in terms of value and volume, but manufacturing export is still marginal. Financial and non-financial incentive to export sector has a significant impact on increasing growth of both in the short run and long run. Therefore, according to this study export incentive provided by the government to export sector leads to increase the performance of export. Similarly, Tewelde (2015) also conclude that export incentive and export growth have positive relationships and incentives have an impact both in volume and value in the long run as well as in the short run.

On the contrary, another study conducted by Mulu and Ashagre (2017) with the methodology of the qualitative method and triangulated technique founds the result of export incentive faces different problems like efficient bureaucracy and coordination. The incentives provided to export sector of Ethiopia are insufficient to stimulate the performance of export and they are exposed to rent-seeking by private sectors. Therefore, the provided scheme of export incentive is failed to boost export performance. To support the above study, on October 11, 2017 National Bank of Ethiopia devaluates exchange rate by $15 \%$ because of shortage of foreign exchange reserve and insufficient export performance(Muluken, 2017).

Therefore, the studies conducted on nexus between export incentive and export performance have different results. This study is conducted in order to scrutinize the nexus between provided export incentive and export performance Ethiopia.

\section{Research Methodology}

\subsection{Research Design}

Explanatory or causal research design is used in this research because of it is important to assess the impact of independent variables on the dependent variable. The causal research design is identified because temporal sequence, concomitant variation and no spurious criteria's are available between variables. It is important to scrutinize the causal relationship between export incentive and export performance, GDP and export performance, 
and other explanatory variables.

This study uses the quantitative type of data collected from the different organization from 1983 to 2017 because it is crucial for the time series analysis. Both dependent and independent variables are macroeconomic variables and they are expressed in the form of quantitative form in the model.

The study uses secondary data collected from Ethiopian Revenue and customs authority (ERCA),WB, NBE and COMSTAT. The export amount, real exchange rate, Gross capital formation, real Gross Domestic Product (GDP) and inflation are collected from National Bank of Ethiopia (NBE). An export incentive is collected from Ethiopian Revenue and customs authority (ERCA). External Debt Stock (EDS) is collected from World Bank (WB).

\subsection{Method of Data Analysis}

This study uses quantitative research method and uses both the descriptive and econometric method of data analysis. To analyze and answer research question what is the trend of Ethiopian export performance the study uses descriptive method of analysis. Tables and graphs are used under the descriptive analysis for further illustration the variables expressed in terms of percentages. Therefore, descriptive method of analysis used to explain trend of variables and explain the data in terms of percentage, mean and median.

The econometric analysis also used for answering the question what is long run and short run relationship between export incentive and export performance. It is also important in the testing of the model, estimation of the model and for testing hypothesis. To analyze these statistical packages E- views 10 is used.

\subsection{Model Specification}

The model used in this thesis is formulated by assuming that the effect of independent variables is carried out in a production function of classical economics framework. Therefore, according to classic economic growth theory, growth is determined by two inputs, capital, and labor, which are paid their marginal products and they assume a Cobb-Douglas production function.

$$
\mathrm{Y}(\mathrm{t})=\mathrm{f}\left(k^{\alpha}(\mathrm{t}) L^{1-\alpha}(\mathrm{t})\right.
$$

Where $\mathrm{Y}$ is output, $\mathrm{k}$ is capital and $\mathrm{L}$ is labor and assumed to grow exogenously whereas $\alpha$ is a parameter. By insertingthe above equation in logarithm from it can converted in to linear form as follows

$$
\operatorname{LNY}(t)=\alpha \operatorname{LN} k(t)+(1-\alpha) L N L(t)
$$

In addition, Ashenafi and Getaneh (2013) use functional form to show the relationship between export incentive and export performance by using the production function as follows;

$$
E X P G=\mathrm{f}\left(F I S C I, F I N I, G D P_{R}, R E E R\right)
$$

Where EXPG is export growth, FINI is financial incentive, FISCI is fiscal incentive, GDP-R is real gross domestic product and REER is real exchange rate.

Therefore, it is rational by using production function to show the relationship between export incentive and export performance. By extending the above equation the model of this study is developed using the econometric model as follows.

$$
\begin{gathered}
\operatorname{LNEx}(t)=\alpha_{0}+\alpha_{1} \operatorname{LnREGDP}(t)+\alpha_{2} \operatorname{LnG} f f(t)+\alpha_{3} \operatorname{LnEDS}(t)+\alpha_{4} \operatorname{Inc}(t)+\alpha_{5} \operatorname{Reer}(t)+\alpha_{6} \operatorname{Inf}(t) \\
+\varepsilon i
\end{gathered}
$$

Where: $\operatorname{LnEx}(\mathrm{t})=$ the Natural logarithm of export at time $\mathrm{t}$

$\operatorname{LnREGDP}(\mathrm{t})=$ the Natural logarithm of real gross domestic product at time $\mathrm{t}$

$\operatorname{Ln} \operatorname{Gcf}(\mathrm{t})=$ the logarithm of growth capital formation at time $t$

$\operatorname{LnEDS}(\mathrm{t})=$ the natural logarithm of external debt stock at time $\mathrm{t}$

Inc $(\mathrm{t})=$ the export incentive at time $\mathrm{t}$

$\operatorname{REER}(\mathrm{t})=$ the real exchange rate at time $\mathrm{t}$

$\operatorname{Inf}(\mathrm{t})=$ yearly inflation at time $\mathrm{t}$,

$\varepsilon i=$ the error term and

$\alpha$ 's $=$ are parameters.

\section{Results and Discussion}

\subsection{Unit Root Test}

Many macroeconomic and financial time series data like real GDP, real exchange rate, the market price of goods and others exhibit non-stationary in the mean or they have trending behavior. The non-stationary of these variables should be adjusted in order to solve the problem of erroneous relationships between the dependent and independent variables. Therefore, unit root test is important to check each series data has the unit root or not. If the data has a unit root, then the data must be transformed into stationary form through differencing before analysis. 
If the data are trending, then there are two common trend removals; first differencing and time trend regression. First differencing is suitable for I(1) time series and time-trend regression is suitable for trend stationary I(0) time series. Consequently, unit root tests can be used to determine the trending data should be first differenced or regressed on deterministic functions of time to render the data stationary.

The standard Augmented Dickey-Fuller (ADF) and Phillips Perron (PP) tests are vital instruments to carry out unit root test. Furthermore, ARDL (Autoregressive Distributed Lagged) model can be functional to variables integrated order of one I (1) and some variables integrated order of zero I (0). Nevertheless, it is not applicable to the variables integrated of order two I (2).

The null hypothesis of unit root test is that the time series data under examination has unit root whereas the alternative hypothesis assertions that the time series data is stationary. The null hypothesis of unit root test is rejected when the ADF or PP test statistic in absolute terms /p-value/ is lower than $\alpha$ value and fails to reject the null hypothesis if the absolute value of ADF or PP test statistic /p values/ is higher than $\alpha$ values. The result of the test for variables at the integrated order of zero I ( 0$)$ and integrated order of one I ( 1 ) is presented in the following table 4.1 .

The Akaike information criterion (AIC) is used to determine the optimal lag length of each variable automatically. Furthermore, it is recommended to choose the maximum of two optimal lag for each variable for annual data. Automatically determination of time series data using the lag length helps to get the valid result and interpretations.

The test was undertaken by Eviews version 10 and it is done by two alternative specifications. First, it is tested with constant but no trend, second with both constant \& trend. Except INCE (incentive), REER (real exchange rate) and INF (inflation) the other variables are in logarithmic forms. Meanwhile, INCE is represented by dummy variable 0 and 1; 0 represents years of export without incentive and 1 represents years with export incentive. Under normal condition, the inflation rate is usually expressed in percentage. The real exchange rate /REER/ is also expressed as the ratio of the price level abroad and the domestic price level; therefore there is no need of converting data to logarithm form.

Table 4. 1 ADF Unit Root Test Results

\begin{tabular}{|c|c|c|c|c|c|c|}
\hline $\begin{array}{l}\text { Variables } \\
\text { (at level and 1st } \\
\text { difference) }\end{array}$ & $\begin{array}{l}\text { t-stat } \\
\text { (with } \\
\text { intercept } \\
\text { but no } \\
\text { trend) } \\
\end{array}$ & $\begin{array}{l}\text { Mackinnon(1996) } \\
\text { One sided p } \\
\text { values }\end{array}$ & $\begin{array}{l}\text { t-stat } \\
\text { (with } \\
\text { intercept } \\
\text { and } \\
\text { trend) }\end{array}$ & $\begin{array}{l}\text { Mackinnon(1996) } \\
\text { One sided p } \\
\text { values }\end{array}$ & $\begin{array}{l}\text { t-stat } \\
\text { (with no } \\
\text { intercept } \\
\text { and no } \\
\text { trend) }\end{array}$ & $\begin{array}{l}\text { Mackinnon(1996) } \\
\text { One sided p } \\
\text { values }\end{array}$ \\
\hline LNEXPO & 0.73 & 0.99 & -2.83 & 0.20 & 4.17 & 1.00 \\
\hline D(LNEXPO) & -4.25 & $0.00^{*}$ & -4.32 & $0.01^{*}$ & -3.24 & $0.00^{*}$ \\
\hline INC & -1.58 & 0.48 & -1.57 & 0.79 & 0.00 & 0.68 \\
\hline $\mathrm{D}(\mathrm{INC})$ & -5.74 & $0.00^{*}$ & -5.78 & $0.00^{*}$ & -5.65 & $0.00^{*}$ \\
\hline INF & -5.40 & $0.00^{*}$ & -5.53 & $0.00^{*}$ & -3.99 & $0.00^{*}$ \\
\hline $\mathrm{D}(\mathrm{INF})$ & -8.15 & $0.00^{*}$ & -8.01 & $0.00^{*}$ & -8.29 & $0.00^{*}$ \\
\hline EDS & -1.01 & 0.74 & -1.04 & 0.92 & 1.03 & 0.91 \\
\hline $\mathrm{D}(\mathrm{EDS})$ & -4.74 & $0.00^{*}$ & -4.72 & $0.00^{*}$ & -4.69 & $0.00^{*}$ \\
\hline LNGCF & 1.19 & 0.99 & -1.16 & 0.90 & 2.58 & 0.99 \\
\hline D(LNGCF) & -6.83 & $0.00^{*}$ & -7.97 & $0.00^{*}$ & -5.84 & $0.00^{*}$ \\
\hline LNREGDP & 2.77 & 1.00 & -1.37 & 0.85 & 4.95 & 1.00 \\
\hline D(LNREGDP) & -4.08 & $0.00^{*}$ & -5.04 & $0.00^{*}$ & -0.82 & 0.35 \\
\hline REER & -1.69 & 0.42 & -2.28 & 0.42 & -1.23 & 0.19 \\
\hline D(REER) & -3.79 & $0.00^{*}$ & -3.65 & $0.04^{*}$ & -3.82 & $0.00^{*}$ \\
\hline
\end{tabular}

Source: Model Result of Data (2018)

Note ${ }^{*}$ denotes significance at $\mathbf{5 \%}$ level.

$\mathrm{LN}=$ Natural Logarithm

$\mathrm{D}=1^{\text {st }}$ difference and the other variables are mentioned in part three

The above table result shows that the Augmented Dickey Fuller (ADF) test and considered at 5\%levelof significance. The rejection of the null hypothesis is based on Mackinnon (1996) p values. Therefore, the sign * indicates the null hypothesis of the variable is non-stationary / it has unit root/ rejected at 5\% significant level.

The test result shows that all variables are stationary at first difference or I (1) with intercept and with intercept and trend. Inflation is also stationary at level or I (0) with intercept, with intercept and trend, and with no intercept and trend. The Phillips Perron test is also conducted and the test result congruent to Augmented Dickey Fuller (ADF) test. The PP test result is presented in the appendix part of this study. The test result of the variables are stationary at I (0) and at I (1) one of the main criteria for using ARDL 


\subsection{Diagnostic Tests and the Model Stability}

Diagnostic tests are necessary to check the stability and reliability the estimated long run and short-run models. The diagnostic tests are the Serial correlation (Brush and Godfray LM test), Normality (Jaque-Bera test), Heteroscedasticity (Breusch-Pagan-Godfrey test), Functional form (Ramsey's RESET test) and CUMSUM recursive residuals. The tests are also important to check the overall stability of the long-run and short-run coefficients. The following tables show that null hypothesis can be rejected or accepted by comparing the p-values with the significance level of $5 \%$.

Table 4.2 Diagnostic Test for the Long Run ARDL $(2,2,1,0,0,1,0)$

\begin{tabular}{|l|l|l|}
\hline Test statics & LM version & F-version \\
\hline A: Serial correlation LM test & Chi-square $(2)=0.88$ & $\mathrm{~F}(2,18)=0.13$ \\
\hline C: Normality (Jaque-Bera test) & Chi-square(2) $=0.81$ & $\mathrm{~F}(12,20)=0.59$ \\
\hline D: Functional form (Ramsey's RESET test) & t-stastic $=0.8831$ & Not applicable \\
\hline $\mathrm{R}^{2}=0.996 \quad \mathrm{DW}=2.3$ & $\mathrm{~F}(1,19)=0.88$ \\
$\mathrm{~A}:$ Lagrange multiplier test of residual serial correlation & \\
B: Based on the regression of squared residuals on squared & \\
fitted values & \\
C: Based on a test of skewness and kurtosis of residuals & \\
D: Ramsey's RESET test using the square of the fitted values &
\end{tabular}

Source: E-views Result of Data (2018)

The above table shows that the long run ARDL model the diagnostic tests results. Based on the result of the test: A: The serial correlation test result (Brush Cod fray LM test) of residual indicates the null hypothesis of there is no serial correlation between variables is failed to be rejected because of $p$-value (0.87) is greater than the standard significant level (0.05). Therefore, at 5\% level of significance, we have evidence there is no significant serial correlation between independent variables. According to Asye (2017) LM test for testing serial correlation is applied because it avoids the limitation of Durbin Watson test. The traditional DW test statistic is totally inapplicable when the lagged dependent variables appear as regresses.

B: The diagnostic test which shows the variables have no constant variance is the test of heteroskedasticity (Breusch-Pagan-Godfrey) test. The null hypothesis homoscedasticity is failed to reject at 5\% significant level since p-value 0.8077 is greater than the standard significance level of $5 \%$. Therefore, at 5 percent level of significance the variables have constant variance.

$\mathrm{C}$ : The other diagnostic test is the test of normal distribution of the residuals. The null hypothesis is the residuals are normally distributed. The Jaque-Berra normality test indicates that the null hypothesis is failed to reject because of p-value 0.328 is greater than the standard significance level5\%. Therefore, at $5 \%$ level of significance the residuals are normally distributed.

D: The other diagnostic test which tests whether the model suffers from the omitted variable or not (Ramsey's RESET test). The null hypothesis is the model does not suffer from omitted variables and the alternative hypothesis is that the model is suffered by omitted variables. The null hypothesis test for Ramsey's RESET test is failed to reject because p-value 0.88 is greater than the standard significance level 0.05 . Therefore, the model is correctly specified and it does not suffer from the omitted variables.

E: The cumulative sum of recursive residuals (CUSUM) and the cumulative sum of squares of recursive residuals (CUSUMSQ) tests are also conducted in order to the show stability of the model for the long run and short run relationship. The following two figures show the test result of the model stability. From the first figure, we can observe CUSUM test and the test line did not cross the critical upper and lower limits. Likewise, the CUSUMSQ test also shows the test line did not cross the lower and upper critical limits. Therefore, long run and short run model of the study is stable; the estimated models are reliable and efficient. Then, the model is explained by 99.4 percent of the variables. 

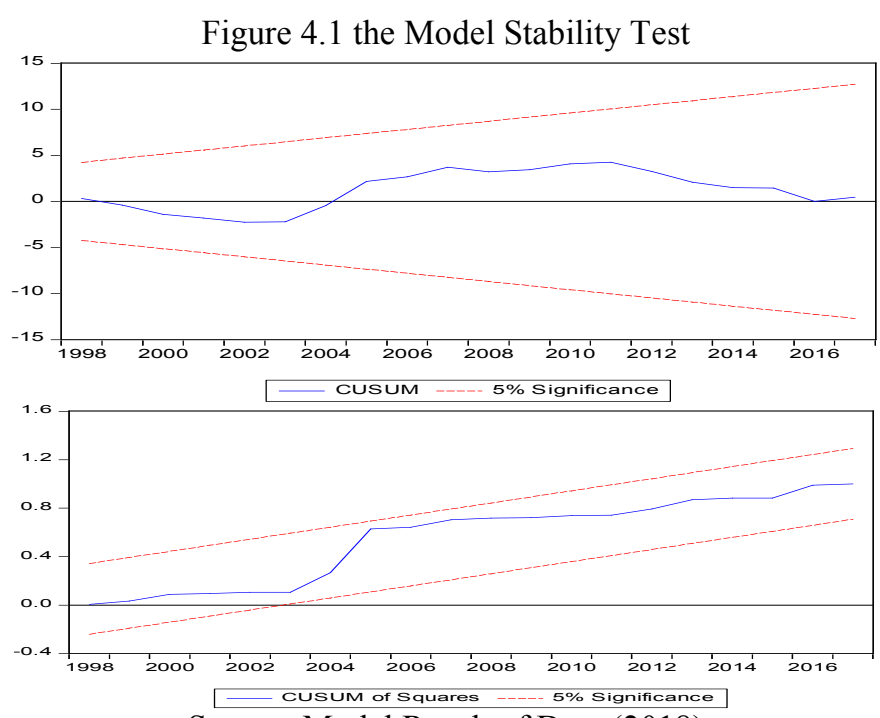

Source; Model Result of Data (2018)

Thus, both unit root test and diagnostic tests fulfill the criteria, the estimated long-run ARDL model in this study is stable because the p-value associated with both the LM version and the F version of the statistic was unable to reject the null hypothesis specified for each test and CUSUM test shows the model stability lines are in between above and lower limits.

\subsection{Long Run ARDL Bounds Test for Co-integration}

Both unit root test and diagnostic tests pass the criteria, therefore, the model is appropriate but one last test is needed in order to check long-run relationship. The bound test for co-integration of variables to the dependent variables is tested. The ARDL model specified in the previous chapter (i.e equation 4) with the maximum lag length of order two was spontaneously chosen because Pesaran and Shine (1999) recommended using a maximum of two lag lengths for the annual data (Tewodros,2015). Further, AIC also used to determine the optimal lag length but under this study, the optimal lag length that minimizes AIC is 2.

The F-test through the Wald test (Bound test) is conducted in order to realize the coefficients of independent variables are significant or not. The Wald test of the collected data shows the estimated long-run coefficients of export incentive, real GDP, real exchange rate, gross capital formation, external debt and inflation rate. The Fstatistic value is compared with the lower bound and upper bound critical values (I (0) and I (1)).

Table 4. 3 F- Test through the Wald Test (Bound Test)

\begin{tabular}{|l|l|l|l|l|l|}
\hline Test statistic & P Value & \multirow{2}{*}{$\mathrm{K}$} & Critical value bound & \multicolumn{2}{l|}{} \\
\cline { 4 - 6 } & & & Significance level & $\mathrm{I}(0)$ bound & $\mathrm{I}(1)$ bound \\
\hline F-statistic & \multirow{2}{*}{6} & $10 \%$ & 2.879 & 4.11 \\
& & & $5 \%$ & 3.426 & 4.79 \\
\cline { 3 - 6 } & & $1 \%$ & 4.704 & 6.54 \\
\hline
\end{tabular}

Soure: Model Reseultsof Data (2018)

$\mathrm{H}_{0}: \beta_{1}=\beta_{2}=\beta_{3}=\beta_{4}=\beta_{5}=\beta_{6}=0$ (there is no long run relationship)

$\mathrm{H}_{\mathrm{A}}: \beta_{1}=\beta_{2}=\beta_{3}=\beta_{4}=\beta_{5}=\beta_{6} \# 0$ (there is long run relationship)

The above table illustrates the calculated F-static 11.78 is higher than the upper bounds of the critical values at all significance levels. We reject the null hypothesis of all the parameters are equal to zero (there is no long-run relationship between dependent and independent variables). Therefore, there are long-run relationships between export and real GDP, real exchange rate, export incentive, inflation, external debt, and gross capital formation at $5 \%$ level of significance.

\subsection{Long Run ARDL Model Estimation}

The bound test for co-integration shows that there is the long run relationship between real export and the independent variables (export incentive, real GDP, real exchange rate, gross capital formation, inflation and external debt). In this part long run ARDL model estimation is conducted in order to identify the extent of the relationship. 
Table 4. 4 Estimated Long Run Coefficient Using ARDL $(2,2,1,0,0,0,1)$

\begin{tabular}{|l|l|l|l|}
\hline \multicolumn{4}{|c|}{ Dependent variable LNEXPO } \\
\hline Repressors & Coefficient & Standard Error & T-Ratio[Prob] \\
\hline INC & 1.68 & 0.373 & $4.51(0.00)^{* *}$ \\
\hline LNREGDP & 2.68 & 0.865 & $3.098(0.01)^{*}$ \\
\hline INF & 0.008 & 0.003 & $2.14(0.04)^{*}$ \\
\hline LNEDS & -0.26 & 0.128 & $-1.26(0.09)$ \\
\hline LNGCF & 0.193 & 0.305 & $0.63(0.53)$ \\
\hline REER & -0.09 & 0.35 & $-0.25(0.80)$ \\
\hline
\end{tabular}

Source: Model Result of Data (2018)

Note: $* *$ and ${ }^{*}$ represents the significance of coefficients at $1 \%$ and $5 \%$ significance levels, respectively.

The above table 4.4 designates the long run test result of ARDL model result of all the variables and their significant level. Export incentive, real GDP and inflation are significant at real 5\% significance levels. However, real effective exchange rate, gross capital formation external debt stocks are not significant at $5 \%$ significance level.

The long run relationship between export incentive and export performance is significant at 5 percent level of significant. The relationship between the variable in the model is in a log-linear form and the coefficients can be interpreted as elasticity with respect to export. The coefficient of export incentive (INC) is 1.68.Thus, holding other variables constant a one percent increase in export incentive brought a 1.68 percent increase in export. Therefore, providing export incentive to export sector is the most significant and positively affects the export performance in the long run.

This result is in-line with the theory of incentive which is providing incentive will raises the amount of productivity. Especially, the first group led by Eisenberger \& Cameron, Eisenberger, Rhoades, \&Cameron, advocate the properly designed incentive systems are consistently successful, and provide evidence that when other methods are not working, incentive programs can dramatically increase performance of the activity. The result also congruent with new trade theories based on market imperfection, infant industry argument and neo mercantilism theory providing incentive will stimulate the economy. Besides, this result is consistence with study of Munch and Schaur (2015) in Denmark; Ahmad (2015) in Bangladesh; Ashenafi and Getaneh (2013) and Tewelde (2015) in Ethiopia.

However, the lower performance of Ethiopian export growth is not associated to export incentive. So, there may be possible reasons for the deterioration of export performance. The first reason is related to the primary product export because these products are less income elastic and the industrial products account 10 percent. In addition, Ethiopian export is concentrated in industrialized countries has its own impact because these countries have no question about basic needs and they consumed luxuries goods.

Next to export incentive real GDP has significant long run impact on the Ethiopian export performance. The coefficient of real GDP (REGDP) is 2.68.Thus, holding other variables constant a one percent increase in real GDP brought a 2.68 percent increase in export. The significant coefficient of real GDP shows that high production capacity in the long run determines the export performance and total supply of the country's export. Therefore, increase in real GDP has significant and positively affects the growth of export in the long run. Therefore, real GDP has high significance to increase export capacity of the country because as production increases the supply of export will also increases.

The impact of inflation on Ethiopian export performance during the study period has positive relationship and statistically significant at $5 \%$ significance levels. The coefficient of inflation is 0.008 .Thus, holding other variables constant a one percent increase in inflation brought a 0.008 percent increase in export. This shows that producers of Ethiopia produces more due to increasing price of their product because they expect that their products more acceptable by customers. Therefore, during the study period the existed inflation has its own significance on export performance of Ethiopia.

The gross capital formation which has a positive impact on Ethiopian export performance and it is statistically not significant at 5 percent significance level. This indicates that the capital formation during the study period is related to production of domestic consumption and other possible reasons.

To finance investments and infrastructures especially for building industrial zones, the Ethiopian government borrowed from different external financial institution and governments. During the study period, external debt stock has the negative impact on Ethiopian export growth but it is not statistically significant at 5 percent significance level. There might be different possible reasons behind the insignificant result; such as the external debt stock might finance investments not directly related to export or finance for import consumptions. Consequently, during the study period external debt stock does not have the significant impact on export performance.

Likewise, real exchange rate also has a negative impact on Ethiopian real export growth and it is statistically insignificant at 5 percent significance level. But, real exchange rate is the most important factors that stimulate or 
to diminish export performance of countries. Policy makers focus on correcting real exchange rate to determine the export performance. It is important to note that a number of studies on the importance of real exchange rate to exports performance and the relationship between them have been conducted over the years accompanied by mixed results. Hence, in the long run purchased power of country's currency decreases because of devaluation and it has negative impact on export performance.

\subsection{Short Run Error Correction Model (ECM)}

The short run Error Correction Model (ECM) is estimated because it indicates the speed of adjustment to restore equilibrium in the dynamic model. It is important to use one lagged period residual obtained from the estimated dynamic long run model. The coefficient of error correction term indicates how quickly variables converge to equilibrium. Co-integration should have a negative sign and statistically significant at 5 percent level of significant.

Table 4. 5 The Short Run Impact of Explanatory Variables

\begin{tabular}{|l|l|l|l|}
\hline Regressors & Coefficient & Standard Error & T-Ratio[Prob] \\
\hline Ln-EXPO(-1) & 0.472 & 0.85 & $5.512(0.00)^{* * *}$ \\
\hline D(INC) & 0.796 & 0.122 & $6.513(0.00)^{* * *}$ \\
\hline D(REER) & 0.041 & 0.169 & $0.24(0.81)$ \\
\hline D(LNREGDP) & 1.746 & 0.495 & $3.522(0.00)^{* * *}$ \\
\hline LNGCF & 0.091 & 0.140 & $0.646(0.53)$ \\
\hline INF & 0.004 & 0.002 & $2.405(0.03)^{* *}$ \\
\hline LNEDS & 0.003 & 0.053 & $0.053(0.96)$ \\
\hline LNEDS (-1) & 0.232 & 0.081 & $2.941(0.01)^{* *}$ \\
\hline Cointeq(-1) & -0.472 & 0.045 & $-10.35(0.00)^{* * *}$ \\
\hline R-squared & 0.85 & \multicolumn{5}{|l|}{} \\
\hline Adjusted R-squared & 0.82 & 24.72 & \\
\hline F-statistics & 0.000 & \\
\hline Prob(F-statistics ) & \multicolumn{5}{|l}{} \\
\hline
\end{tabular}

Source: Model Result of Data (2018)

Note: the sign $* * *, * *$ and ${ }^{*}$ denotes the coefficients are statistically significant at $1 \%, 5 \%$ and $10 \%$ respectively. First of all it is important to know or test short run relationship between dependent and independent variables under the following hypothesis.

$\mathrm{H}_{0}$ : there is no short run relationship between dependent and independent variables

$\mathrm{H}_{\mathrm{A}}$ : there is short run relationship between dependent and independent variables

As indicated from table 4.5 the null hypothesis there is no short run relationship between export performance and independent variables is rejected because $p$-value $(0.000)$ less than level of significance $(\alpha=0.05)$.

In addition, the estimated error correction coefficient -0.47 is significant at $5 \%$ level of significance and has the correct negative sign. As cited from Tewodros (2015) according to Bannerjeet al. (2003) the coefficient of the error correction term implies that the deviation from long run equilibrium level of export in the current period is corrected by $47 \%$ in the next period bring back to equilibrium when there is a shock to a steady state relationship. In other words approximately 47 percent of the disequilibrium from the previous year's shock converges back to the long run equilibrium in the current year.

Further, there are two indicators to show short run relationship between export and independent variables which are R-squared and significant level of F-statistics. As depicted from the above table the coefficient of determination (adjusted R-squared) shows that the export is explained by the variations of the independent variables in the model is $82 \%$. Moreover, the F-statistics is significant that shows the model is good to explain the relationship between the variables in the short run.

From the above table 4.5 we can observe test result of the relationship between export and independent variable sin the short run. The test result is interpreted as follows;

Export with one lag length affects the current export during the study period because export with one lag length in the short run is statistically significant at 5\% significance level. Other things remains constant a one percent increase in previous export will increase the export by 0.47 percent in the short run. Previous export increases production capacity of the current export. Therefore, the previous export performance affects positively the current export performance.

Export incentive has positive and statistically significant impact in the short run at 5\% significance level. Therefore, other things remains constant a one percent increase in export incentive will increase the total export by 0.79 percent in the short run. This study is in line with Ashenafi and Getahun (2013) and Tewelde (2015), it is also supported by neo mercantilism and infant industry argument which specifies that providing export incentive has its own impact on increasing export performance. The marginal performance of the current Ethiopian export performance is due to other reasons such as export is concentrated on agricultural products which are less elastic 
to income and other possible reasons.

Inflation is also the significant factor in Ethiopian export in the short run at 5\% significance level. Therefore, other things being constant a one percent increase in inflation will lead a 0.004 percent increase in export. Like that of the long run real GDP has the positive impact in the short run and statistically significant impact in the short run at 5\% significance level. This means holding other variables constant a one percent increase in GDP will increase export by 1.7 percent. Also, external debt with one lag length affects export at 5\% significant level. So, holding other variables constant a one percent increase in external debt stock in the previous year will increase export by 0.23 percent. Therefore, export incentive, export with one lag time, external debt with one lag time, real GDP and inflation are determinant factors in the short run during the study period.

The real exchange rate in the short run has the positive impact but it is not statistically significant at $5 \%$ significance level. The national bank made devaluation in order to boost export performance in the short run but during the study period, the real exchange rate is not the statically significant factor to influence export.

Similar to the long run, the gross capital formation is insignificant at $5 \%$ significant level. So, gross capital formation in the short run has not that much influence on the export performance. Theoretically, the gross capital formation is the major determinant to influence export performance but during the study time, the result is different.

\section{Conclusions and Recommendations \\ 5.1 Conclusion}

The main objective of this study is to investigate the nexus between export incentive and Ethiopian export during the period from 1983 to 2017. The study used Autoregressive Distributed Lag (ARDL) model in order to determine the long run and the short run relationship between export performance and independent variables (export incentive, real GDP, real exchange rate, external debt stock, inflation and gross capital formation). Before applying the ARDL model, all the variables are tested for their time series properties (stationary properties) using the ADF and PP tests. ADF test result shows all the variables are stationary at their first difference with intercept and trend. The bound test also conducted to identify the presence of long-run relationships between export and explanatory variables.

The finding part shows that holding the other variables constant a one percent increases in export incentive will increase export by 1.68 percent in the long run during the study period. Similarly, one percent increase in real GDP will result to increase export by 2.68 percent in the long run and during the study period. In addition, one percent increase in inflation will result to increase export by 0.008 percent during the study period. Therefore, export incentive, real GDP, and inflation have a positive impact on export performance during the study period.

Error correction model shows the result of the short-run relationship between real export and independent variables. The result of the study shows that one period lagged value of export, export incentive, real GDP, one period lagged value of external debt and inflation have the positive impact on export and statically significant at 5 percent level of significance.

Holding the other variables constant one percent increases in previous export increases current export by 0.47 percent in the short run during the study period. Similarly, holding the other variables constant one percent increase increases export incentive will increase export by 0.79 percent in the short run during the study period. In addition, Holding the other variables constant one percent increases in real GDP increases export by 1.75 percent, Holding the other variables constant one percent increase in external debt with one lag value increases export by 0.23 percent, and Holding the other variables constant one percent increase in inflation increases export by 0.004 percent. Therefore, during the study period export incentive, real GDP, external debt with one lag value and inflation have the positive impact on export performance and they are statically significant in the short run during the study period whereas gross capital formation and real exchange rate are not statically significant at 5 percent level of significance.

The short-run error correction model (ECM) formulation reveals that there is the convergence towards equilibrium in the long run and the adjustment is fairly strong (47\%) per annum and statistically significant at 5 percent of the level of significance.

\subsection{Recommendations}

Based on the finding of the study there are prospects of increasing export performance. The researcher addresses following recommendations:

* Since export incentive is significant factor for Ethiopian export performance both in the long run and short run, the government should give greater emphasis by continuing the current trends of incentives which are the engines for export growth.

* The government also might give special attention for effective administration of export incentive because it is vast in nature and difficult to know which sector is effectively uses the provided incentive. This can be done by creating one case team in ERCA or in Export promotion agency. 
* The general nature of the provided incentive whether the sector is effective or not should come to specific and provide additional incentives for organizations based on the contribution to export like quality, quantity, value addition, skilled manpower development, by creating employment opportunity etc.

* The researcher also recommends further study on the provided incentive at firm's level data, at sector level and economic implication of export incentive to society.

\section{Reference}

[1] Ahmad,I. (2015).The Value of export incentives. The Lahore Journal of Economics, 20(2), 99-127. Retrieved from http://www.lahoreschoolofeconomics.edu.pk

[2] Ahuja, R. (2001). Export incentive in India within WTO framework. Retrieved from http://icrier.org/pdf/rajeev72try.PDF

[3] Asaye M.(1998).Determinants of economic growth in Ethiopia: A time series analysis. Sent marry university, Addis Abeba.

[4] Ashenafi B. and Getaneh B. (2014). Export trade incentives and export growth nexus: Evidence from Ethiopia. British Journal of Economics, Management \& Trade,4(1), 111-128. Retrieved from www.sciencedomain.org

[5] Azasu, S.(2004). Using pay and benefits in real estate firms an initial look at the Swedish experience. Royal Institute of Technology, Stockholm. Retrieved from http://eres.scix.net

[6] Azmera A. (2013). The role of government policy package in boosting export ; A comparative Study of Ethiopia, SouthKorea and Vietnam. IFSMRC AIJRM, 01(01), 21-22.Retrieved from http://ifsmrc.org/sites/default/files/journals

[7] Bliss, C. (1987). The new trade theory and economic policy. Oxford review of economic policy, 3(1), 2036.Retrieved from http://www.jstor.org/stable/23606096.

[8] Ditter,J. (2010). International Trade - Theories and Reality.Universitat Siegen. Retrieved from https://www.wiwi.uni-siegen.de

[9] Defever,F., Reyes,J., Riano, A. and Varela,G. (2017).The effectiveness of export subsidies in Nepal. Policy Research Working Paper 8009 Retrieved from http://documents.worldbank.org

[10] Defevery, F. and Riano, A.(2012). China's Pure Exporter Subsidies. Retrieved from https://pdfs.semanticscholar.org

[11] Fowowe, B.(2013). Do fiscal incentives promote investment? Empirical evidence from Nigeria.The Journal of Developing Areas, 47(2), 17-35.Retrieved from http://www.jstor.org.

[12] Jordaan,D. (2012). An overview of incentives theory and practice: A focus on the agro-processing industry in South Africa. Retrieved from http://www.nda.agric.za

[13] Julian,C. and Ali,Y. (2009). Incentives to export for Australian export market ventures. Retrieved from https://epubs.scu.edu.au

[14] Kemal,A. (1979). Infant Industry argument, protection and manufacturing industries of Pakistan.The Pakistan Development Review, 18,(1), 1-19.Retrieved from http://www.jstor.org/stable/41258489.

[15] Kneller, R. and Pisu,M. (2004). Export-Oriented FDI in the UK.Oxford Review of Economic Policy, 20( 3), 424-439. Retrieved from http://www.jstor.org/stable/23607094.

[16] Kripfganz, S. and Schneider, D. (2016). ARDL: Stata module to estimate autoregressive distributed lag models. Retrieved from https://www.stata.com/

[17] Krueger,A. and Tuncer,B. (1984 ). An Empirical Test of the Infant Industry Argument: Reply. The American Economic Review, 74(5), 1112-1113. Retrieved from http://www.jstor.org/stable/573

[18] Laffont, J. and Martimort, D. (2001). The Theory of incentives I : The principal agent model. Retrieved from https://gnunet.org/sites

[19] Miroslava,C. (2013). The Effectiveness of investment incentives in certain foreign companies operating in the Czech Republic. Journal of Competitiveness, 5(1), 108-120. DOI: 10.7441/joc.2013.01.08

[20] Motswapong,M. and Grynberg,R. (2011). The Textile and Clothing Sector in Botswana: Challenges and Opportunities. Botswana Journal of Economics

[21] Mulu G. and Ashagrie D. (2017). Why export promotion efforts failed to deliver? Assessment of the export incentives and their implementation in Ethiopia. Ethiopian development research institute, Working Paper 17, Retrieved from http://www.edri.org.et

[22] Muluken Y. (2017). NBE applies new policies following the $15 \%$ birr devaluation. Capital. Retrieved from http://capitalethiopia.com

[23] Munch, J. and Schaur,G. (2015).The effect of export promotion on firm-level performance. Retrieved from http://www.freit.org/EITI/2015/

[24] Tewelde G. (2015). The effect of export trade tax incentives on export growth: The Case of Ethiopia.Saint Marry University, Addis abeba. Retrieved from http://repository.smuc.edu.et

[25] Tewodros G. (2015). The Determinants of Economic Growth in Ethiopia: A Time Series Analysis.Addisabeba university, Ethiopia. 
[26] Tran,T., Diaw,D. and Rieber,A. ( 2012). International demand spillovers in South-South exports: Application to Sub-Saharan Africa and Developing Asia. Journal of Economic Integration, 27(3), 410-436.Retrieved from http://www.jstor.org/stable/23317241

[27] UNCTAD. (2004). Policy issues in international trade and commodities study series no. 26. Retrieved from http://unctad.org/en

[28] UNCTAD. (2003). Incentive: UNCTAD series on issues in international investment agreements. UNCTAD//IIT/2003/5 Retrieved from http://unctad.org/en

[29] Worlu, R. (2011). Effectiveness of Government Export Support Programs in Nigeria: an Exploratory Inquiry. IJBEMR 2(2), 2229-4848 Retrieved from http://eprints.covenantuniversity.edu.ng/1765/1/ 